\title{
Evaluating the Level of Provincial Ecological Civilization Development in China Using the Double-Benchmark Progressive Method
}

\author{
Xie Yuxi, Zhang Linbo, Luo Shanghua, Yang Jiao, Li Fen, Wang Dewang \\ Chinese Research Academy of Environmental Sciences, Beijing 100012, China
}

\begin{abstract}
To assess the level of provincial ecological civilization development in China, this work constructs an evaluation index system that includes four areas, 10 targets, and 25 specific indicators. Based on a comparison and improvement of existing data standardization methods, this study puts forward a double-benchmark progressive method as the standardization method, and adopts the comprehensive weighted-index method to evaluate the ecological civilization development level of China's 31 provinces (including provinces, autonomous regions, and municipalities). The results indicate that the ecological civilization development level in China is low, and that the ecological civilization development level of the southeastern coastal areas is higher than those of Central and Western China. In general, gaps still exist between China's ecological-civilization development level, its expected level, and the global level. Although China has made remarkable achievements to date in terms of overall economic and social construction, it is necessary to further strengthen and pay attention to ecological environmental protection, industrial pollution control, industrial optimization, and efficient resource use.
\end{abstract}

Keywords: ecological-civilization development level; provincial ecological civilization evaluation; double-benchmark progressive method; single-benchmark progressive method; maximum-difference normalization method

\section{Research background}

Some institutions and scholars have studied different perspectives of sustainable development and various scales to assess the development of ecological civilization (eco-civilization), such as the evaluation of eco-civilization construction in China [1], the China Green Development Index [2], and the Global Environmental Performance Index [3]. These indicators are broad and comprehensive, reflecting the development of eco-civilization in various countries and cities. However, there continue to be some shortcomings in existing methods to standardize the assessment of specific indicators, such as extreme standardization and Z-score standardization, which are limited in dimensionless processing, and produce processed data that have no practical meaning. In this study, we propose a standardization method called the double-benchmark progressive method and discuss the differences among this method, the standard deviation method, and the single-benchmark progressive method. We evaluate the level of eco-civilization development in 31 provinces, autonomous regions, and municipalities (not including the Hong Kong Special Administrative Region, Macau Administrative regions, and Taiwan) in China in 2014.

\section{Research methods and data sources}

\subsection{Development of the index system}

This study coordinated the overall goal of eco-civilization

Received date: June 30, 2017; Revised date: July 19, 2017

Corresponding author: Zhang Linbo, Chinese Research of Academy of Environmental Sciences, Professor. Major research fields include eco-civilization construction and ecological asset accounting. E-mail: zhanglb@craes.org.cn

Funding program: CAE Advisory Project “Several Strategic Issues on Eco-Civilization Construction (Phase II)" (2015-ZD-16)

Chinese version: Strategic Study of CAE 2017, 19 (4): 060-066

Cited item: Zhang Linbo et al. Evaluating the Level of Provincial Ecological Civilization Development in China Using the Double-Benchmark Progressive Method. Strategic Study of CAE, https://doi.org/10.15302/J-SSCAE-2017.04.010 
construction in China to evaluate economic and social development comprehensively and objectively to develop an index system that included four areas, 10 targets, and 25 indicators. The specific index system is shown in Table 1 .

\subsection{Evaluation methods and data sources}

This study adopted a standardized method for dimensionless normalization, and adopted the analytic hierarchy process (AHP) to assign a weight to each index, eventually used the comprehensive weighted index method to determine the eco-civilization development level. We finally divided the levels of eco-civilization development into five grades, namely Level A $(K \geq 90)$, Level B $(70 \leq K<90)$, Level C $(60 \leq K<70)$, Level D $(50 \leq K$ $<60)$, and Level $\mathrm{E}(K<50)$. The original socioeconomic indicator data were taken from the China's Statistical Yearbook and the Urban Statistical Yearbook, while the statistics on environmental protection, pollution control, and pollution governance were obtained from remote sensing data, environmental monitoring data, and other industry statistics, as well as some relevant research results, such as the habitat quality index and the per capita ecological footprint. Weights and indicators of the data sources are shown in Table 2.

The formula for the comprehensive weighted index method is:

$$
K=\sum_{j=1}^{n} W_{i} \cdot A_{j}
$$

where $K$ is the comprehensive evaluation index, namely, the eco-civilization developmental index, $W_{i}$ is the weight of each indicator, and $A_{j}$ is the score after standardizing each indicator.

In this study, the data standardization method was based on commonly used methods. Three standardized methods were enumerated, i.e. extreme standardization [5], the single-benchmark progressive method [6], and the double-benchmark progressive method. We focused on a comparison of the results of each standardized method. The normalization of the extreme standardization method was based on the maximum and minimum values

Table 1. Eco-civilization index system.

\begin{tabular}{|c|c|c|c|c|}
\hline Areas & Targets & Indicators & Units & Properties \\
\hline \multirow[t]{3}{*}{ Green environment } & $\begin{array}{l}\text { Ecological condition } \\
\text { index }\end{array}$ & Habitat quality & - & Positive \\
\hline & \multirow{2}{*}{$\begin{array}{l}\text { Environmental quality } \\
\text { index }\end{array}$} & Air quality & $\%$ & Positive \\
\hline & & Surface water quality & $\%$ & Positive \\
\hline \multirow[t]{9}{*}{ Green production } & \multirow{3}{*}{$\begin{array}{l}\text { Industry optimization } \\
\text { index }\end{array}$} & Per capita GDP & yuan & Positive \\
\hline & & Tertiary industry added value of GDP proportion & $\%$ & Positive \\
\hline & & R\&D expenditure of GDP proportion & $\%$ & Positive \\
\hline & \multirow{4}{*}{$\begin{array}{l}\text { Resource efficiency } \\
\text { index }\end{array}$} & Unit construction land GDP & ten thousand yuan $/ \mathrm{km}^{2}$ & Positive \\
\hline & & Units of industrial added value of fresh water consumption & t/ten thousand yuan & Negative \\
\hline & & Unit GDP energy consumption & tce/ten thousand yuan & Negative \\
\hline & & Unit planting area fertilizer use & $\mathrm{t} / \mathrm{hm} \mathrm{m}^{2}$ & Negative \\
\hline & \multirow[t]{2}{*}{ Pollution emission index } & Emission intensity of major water pollutants & $\mathrm{t} / \mathrm{km}^{2}$ & Negative \\
\hline & & Emission intensity of major air pollutants & $\mathrm{t} / \mathrm{km}^{2}$ & Negative \\
\hline \multirow[t]{8}{*}{ Green living } & \multirow{5}{*}{$\begin{array}{l}\text { Urban-rural coordination } \\
\text { index }\end{array}$} & Urbanization & $\%$ & Positive \\
\hline & & Per capita disposable income of urban residents & yuan & Positive \\
\hline & & Ratio of income between urban and rural residents & - & Negative \\
\hline & & Rural sanitary latrines penetration & $\%$ & Positive \\
\hline & & Rural drinking water qualification rate & $\%$ & Positive \\
\hline & \multirow[t]{2}{*}{ Urban habitat index } & Per capita green land of parks & $\mathrm{hm}^{2} /$ ten thousand people & Positive \\
\hline & & Built-up area green coverage & $\%$ & Positive \\
\hline & $\begin{array}{l}\text { Green consumption } \\
\text { index }\end{array}$ & Per capita ecological footprint & global hectare & Negative \\
\hline \multirow[t]{5}{*}{ Green governance } & \multirow[t]{2}{*}{ Pollution control index } & Treatment rate of urban domestic sewage & $\%$ & Positive \\
\hline & & Decontamination rate of urban domestic refuse & $\%$ & Positive \\
\hline & \multirow[t]{3}{*}{$\begin{array}{c}\text { Construction } \\
\text { performance index }\end{array}$} & $\begin{array}{l}\begin{array}{l}\text { Environmental protection investment of fiscal expenditure } \\
\text { proportion }\end{array}\end{array}$ & $\%$ & Positive \\
\hline & & Environmental information disclosure rate & $\%$ & Positive \\
\hline & & Area ratio of natural reserves & $\%$ & Positive \\
\hline
\end{tabular}


Table 2. Weights and data sources for each indicator.

\begin{tabular}{|c|c|c|c|c|c|}
\hline $\begin{array}{l}\text { Areas and } \\
\text { weights }\end{array}$ & $\begin{array}{l}\text { Targets and } \\
\text { weights }\end{array}$ & Indicators & Unit & Weights & Data sources \\
\hline \multirow[t]{2}{*}{$\begin{array}{l}\text { Green } \\
\text { environment } \\
(0.25)\end{array}$} & $\begin{array}{c}\text { Ecological } \\
\text { condition index } \\
(0.5)\end{array}$ & Habitat quality & - & 1 & $\begin{array}{l}\text { Use remote sensing data and related } \\
\text { calculation method, referencing to Technical } \\
\text { Regulations of Ecological Environment } \\
\text { Assessment [4] }\end{array}$ \\
\hline & $\begin{array}{l}\text { Environmental } \\
\text { quality index }(0.5)\end{array}$ & Air quality & - & 0.50 & China Environmental Statistical Yearbook \\
\hline \multirow{9}{*}{$\begin{array}{l}\text { Green } \\
\text { production } \\
(0.25)\end{array}$} & \multirow{3}{*}{$\begin{array}{l}\text { Industry } \\
\text { optimization } \\
\text { index }(0.4)\end{array}$} & Per capita GDP & yuan & 0.40 & National Bureau of Statistics website \\
\hline & & $\begin{array}{l}\text { Tertiary industry added value of } \\
\text { GDP proportion }\end{array}$ & $\%$ & 0.30 & China Urban Statistical Yearbook \\
\hline & & $\begin{array}{l}\text { R\&D expenditure of GDP } \\
\text { proportion }\end{array}$ & $\%$ & 0.30 & Provincial Urban Statistical Yearbook \\
\hline & \multirow{4}{*}{$\begin{array}{c}\text { Resource } \\
\text { efficiency index } \\
(0.3)\end{array}$} & Unit construction land GDP & $\begin{array}{l}\text { ten thousand } \\
\text { yuan } / \mathrm{km}^{2}\end{array}$ & 0.25 & China Environmental Statistical Yearbook \\
\hline & & $\begin{array}{l}\text { Units of industrial added value } \\
\text { of fresh water consumption }\end{array}$ & $\begin{array}{l}\mathrm{t} / \text { ten thousand } \\
\text { yuan }\end{array}$ & 0.25 & Provincial Urban Statistical Yearbook \\
\hline & & Unit GDP energy consumption & $\begin{array}{l}\text { tce/ten thousand } \\
\text { yuan }\end{array}$ & 0.30 & China Energy Statistical Yearbook \\
\hline & & Unit planting area fertilizer use & $\mathrm{t} / \mathrm{hm}^{2}$ & 0.20 & China Environmental Statistical Yearbook \\
\hline & \multirow{2}{*}{$\begin{array}{l}\text { Pollution } \\
\text { emission index } \\
(0.3)\end{array}$} & $\begin{array}{l}\text { Emission intensity of major } \\
\text { water pollutants }\end{array}$ & $\mathrm{t} / \mathrm{km}^{2}$ & 0.50 & \\
\hline & & $\begin{array}{l}\text { Emission intensity of major air } \\
\text { pollutants }\end{array}$ & $\mathrm{t} / \mathrm{km}^{2}$ & 0.50 & \\
\hline \multirow{7}{*}{$\begin{array}{l}\text { Green living } \\
(0.25)\end{array}$} & \multirow{4}{*}{$\begin{array}{l}\text { Urban-rural } \\
\text { coordination } \\
\text { index }(0.4)\end{array}$} & Urbanization & $\%$ & 0.20 & China Environmental Statistical Yearbook \\
\hline & & $\begin{array}{l}\text { Per capita disposable income of } \\
\text { urban residents }\end{array}$ & yuan & 0.20 & \\
\hline & & $\begin{array}{l}\text { Rural sanitary latrines } \\
\text { penetration }\end{array}$ & $\%$ & 0.20 & China Environmental Statistical Yearbook \\
\hline & & $\begin{array}{l}\text { Rural drinking } \\
\text { water qualification rate }\end{array}$ & $\%$ & 0.20 & \\
\hline & \multirow[t]{2}{*}{$\begin{array}{l}\text { Urban habitat } \\
\text { index }(0.4)\end{array}$} & Per capita green land of parks & $\begin{array}{l}\mathrm{hm}^{2} / \text { ten thousand } \\
\text { people }\end{array}$ & 0.45 & \\
\hline & & Built-up area green coverage & $\%$ & 0.55 & \\
\hline & $\begin{array}{l}\text { Green } \\
\text { consumption } \\
\text { index }(0.2)\end{array}$ & Per capita ecological footprint & global hectare & 1 & $\begin{array}{l}\text { Reference to the CAS Institute of Geography } \\
\text { and WWF related research data }\end{array}$ \\
\hline \multirow{5}{*}{$\begin{array}{l}\text { Green } \\
\text { governance } \\
(0.25)\end{array}$} & $\begin{array}{l}\text { Pollution control } \\
\text { index }(0.5)\end{array}$ & $\begin{array}{l}\text { Treatment rate of urban } \\
\text { domestic sewage }\end{array}$ & $\%$ & 0.50 & China Environmental Statistical Yearbook \\
\hline & & $\begin{array}{l}\text { Decontamination rate of urban } \\
\text { domestic refuse }\end{array}$ & $\%$ & 0.50 & China Environmental Statistical Yearbook \\
\hline & $\begin{array}{l}\text { Construction } \\
\text { performance } \\
\text { index }(0.5)\end{array}$ & $\begin{array}{c}\text { Environmental protection } \\
\text { investment of fiscal expenditure } \\
\text { proportion }\end{array}$ & $\%$ & 0.30 & China Environmental Statistical Yearbook \\
\hline & & $\begin{array}{l}\text { Environmental information } \\
\text { disclosure rate }\end{array}$ & $\%$ & 0.30 & $\begin{array}{c}\text { Reference to Environmental Publicity and } \\
\text { Education Center }\end{array}$ \\
\hline & & Area ratio of natural reserves & $\%$ & 0.40 & China Environmental Statistical Yearbook \\
\hline
\end{tabular}

of the index data. The single-benchmark progressive method uses only the target value to normalize each index. The doublebenchmark progressive method has been improved from the single benchmark progressive method and selects a set of several target normalized values.

\subsubsection{Extreme standardization}

In this method, the original data is linearly transformed. Let $\min X$ and $\max X$ be the minimum and maximum values of $A$ respectively, and one of the original values $x$ of $A$ be normalized by max-min into the value $X$ interval $[0,1]$. Then, the specific 
formula is:

$$
A_{i j}=\left\{\begin{array}{l}
\frac{X_{i j}-\min \left(X_{i j}\right)}{\max \left(X_{i j}\right)-\min \left(X_{i j}\right)}, \text { when } X_{i j} \text { is a positive indicator } \\
\frac{\max \left(X_{i j}\right)-X_{i j}}{\max \left(X_{i j}\right)-\min \left(X_{i j}\right)}, \text { when } X_{i j} \text { is a negative indicator }
\end{array}\right.
$$

where $A_{i j}$ is the value of the indicator data after normalization, $X_{i j}$ is the original value of the indicator before normalization, max $\left(X_{i j}\right)$ is the maximum value of the indicator before normalization; $\min \left(X_{i j}\right)$ is the minimum value of the indicator before normalization, $i$ represents the $i$ th year, and $j$ represents the indicator's sequence.

\subsubsection{Single-benchmark progressive standardization}

This method uses the unique target value of each indicator as a reference and assigns indicators according to the corresponding requirements (Fig. 1). The specific formula is:

$$
\begin{aligned}
& A_{i j}= \begin{cases}\frac{X_{i j}}{S\left(X_{i j}\right)}, 0 \leqslant X_{i j} \leqslant S\left(X_{i j}\right) & \text {, when } X_{i j} \text { is a positive } \\
1, X_{i j} \leqslant S\left(X_{i j}\right) & \text { indicator }\end{cases} \\
& A_{i j}= \begin{cases}1-\frac{X_{i j}-S\left(X_{i j}\right)}{S\left(X_{i j}\right)}, X_{i j} \geqslant S\left(X_{i j}\right) & \text { when } X_{i j} \text { is a } \\
1,0 \leqslant X_{i j} \leqslant S\left(X_{i j}\right) & \text { negative indicator (4) }\end{cases}
\end{aligned}
$$

Note: If $A_{i j}<0$, the value is 0 ; If $A_{i j}>100$, the value is 100 .

where $A_{i j}$ is the value of the indicator data after normalization, $X_{i j}$ is the original value of the indicator before normalization, $S_{(X i j)}$ is the corresponding benchmark value of the indicator, $i$ represents the $i$ th year, and $j$ represents the indicator's sequence.

\subsubsection{Double-benchmark progressive standardization}

This method improves upon the basic single-benchmark progressive method. Two target values are selected as the benchmark reference, and the corresponding indicators are assigned by the degree at which each indicator approaches the target value. Two target values are assigned to values A and C, namely, the corresponding scores were 60 and 90 points after standard-

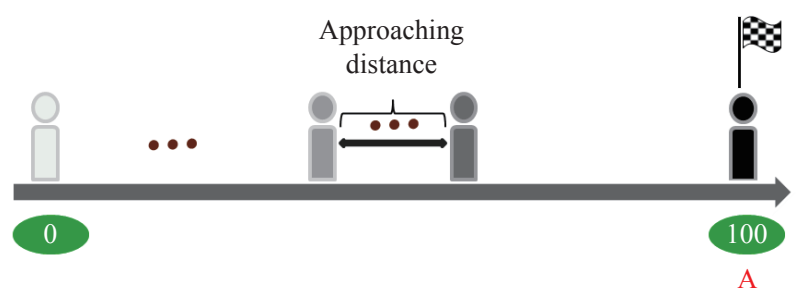

Fig. 1. Schematic of the single-benchmark progressive normalization method. ization, respectively. The selection of values A and $\mathrm{C}$ is mainly based on the relevant industry standards in China and each department, the relevant planning, or other requirements of the country, and the status quo of the cities with the same level of development domestically and abroad, such as the National Ecological Civilization Demonstration Model (Trial) (Draft); Urban Landscape Evaluation Criteria (GB50563-2010); Eco-county, Eco-city, Eco-province Construction Indicators (Trial); Zero-growth Action Plan for Fertilizer Use by 2020; National Medium and Long Term Science and Technology Development Plan (2006-2020); New National Urbanization Plan (2014-2020), and World Bank data for middle and high-income countries in 2014. The specific target value is shown in Table 3. For some indicators with no reference, the target value can be set according to the statistical distribution feature of each index. This means, the original data were selected at $60 \%$ and $90 \%$ of the overall position of the indicator's value (Fig. 2). The specific formula is:

$$
A_{i j}=\left[\left(X_{i j}-S_{\mathrm{C}\left(X_{i j}\right)}\right) \times \frac{\left(S_{\mathrm{A}}-S_{\mathrm{C}}\right)}{\left(S_{\mathrm{A}\left(X_{i j}\right)}-S_{\mathrm{C}\left(X_{i j}\right)}\right)}+S_{\mathrm{C}}\right] \times 0.01
$$

Note: If $A_{i j}<0$, the value is 0 ; If $A_{i j}>100$, the value is 100 .

where $A_{i j}$ is the value of the indicator data after normalization, $X_{i j}$ is the original value of the indicator before normalization, $S_{\mathrm{A}\left(X_{i j}\right)}$ is benchmark A of the indicator, $S_{\mathrm{C}\left(X_{i j}\right)}$ is benchmark $\mathrm{C}$ of the indicator; $S_{\mathrm{A}}$ is the value of the indicator corresponding to benchmark A (60 points), and $S_{\mathrm{C}}$ is the value of the indicator corresponding to benchmark C (90 points); $\frac{\left(S_{\mathrm{A}}-S_{\mathrm{C}}\right)}{\left(S_{\mathrm{A}\left(X_{i j}\right)}-S_{\mathrm{C}\left(X_{i j}\right)}\right)}$ is the change in the value along with the increase or decrease in each indicator, where $i$ represents the year, and $j$ represents the indicator's sequence.

\section{Results and discussion}

\subsection{Comparison and analysis of the results of various evaluation methods}

This study compared the single-benchmark progressive method and the double-benchmark progressive method, using the

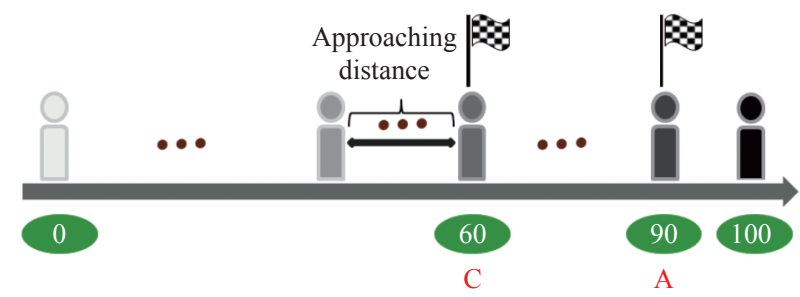

Fig. 2. Schematic diagram of the double-benchmark progressive normalization method. 
extreme standardization method as the reference. The results are shown in Tables 4 and 5.

The standard method, based on mathematical principles, is a dimensionless normalization treatment of the original indicator data. However, the data have no practical meaning. The benchmark progressive method defines each indicator practically by considering the relevant target requirements of the domestic industry standard, the planning target value, and the international

level. Furthermore, this study determined $\frac{\left(S_{\mathrm{A}}-S_{\mathrm{C}}\right)}{\left(S_{\mathrm{A}\left(X_{i j}\right)}-S_{\mathrm{C}\left(X_{i j}\right)}\right)}$ (see the "double-benchmark progressive method"), which represents value change, along with the increase or decrease of each indicator and the relationship between the original value of the index and the normalized value. This value reflects the actual level of eco-civilization development, or whether it conforms to the corresponding level of development in China and the world. The double-benchmark progressive method also suggests how to select the target value when no specified reference value exists for the indicators, which can resolve the value selection problem. This means, the target value can be set according to the statistical distribution feature of each index.

Table 3. Benchmark selection.

\begin{tabular}{|c|c|c|c|c|}
\hline Types & Indicator & Unit & The value of $\mathrm{A}$ & The value of $\mathrm{C}$ \\
\hline \multirow[t]{12}{*}{ National or industry standard } & Air quality & $\%$ & 85 & 60 \\
\hline & Surface water quality & $\%$ & 85 & 70 \\
\hline & Rural sanitary latrines penetration & $\%$ & 95 & 60 \\
\hline & Rural drinking water qualification rate & $\%$ & 95 & 60 \\
\hline & Environmental information disclosure rate & $\%$ & 80 & 50 \\
\hline & Area ratio of natural reserves & $\%$ & 20 & 14.8 \\
\hline & Unit GDP energy consumption & tce /ten thousand yuan & 0.2 & 0.7 \\
\hline & Treatment rate of urban domestic sewage & $\%$ & 95 & 85 \\
\hline & Decontamination rate of urban domestic refuse & $\%$ & 95 & 85 \\
\hline & Per capita green land of park & $\mathrm{hm}^{2} /$ ten thousand people & 13 & 7.5 \\
\hline & Built-up area green coverage & $\%$ & 40 & 36 \\
\hline & Unit planting area fertilizer use & $\mathrm{t} / \mathrm{hm}^{2}$ & 0.25 & 0.5 \\
\hline Related national planning & R\&D expenditure of GDP proportion & $\%$ & 2.5 & 2.1 \\
\hline \multirow{4}{*}{$\begin{array}{l}\text { Domestic and foreign city } \\
\text { analogy }\end{array}$} & Urbanization & $\%$ & 80 & 60 \\
\hline & Per capita GDP & yuan & 60000 & 30000 \\
\hline & Tertiary industry added value of GDP proportion & $\%$ & 60 & 40 \\
\hline & Per capita disposable income of urban residents & yuan & 18000 & 53000 \\
\hline \multirow[t]{8}{*}{ Statistical characteristics } & Habitat quality & - & 80 & 50 \\
\hline & Unit construction land GDP & ten thousand yuan $/ \mathrm{km}^{2}$ & 60000 & 30000 \\
\hline & $\begin{array}{l}\text { Units of industrial added value of fresh water } \\
\text { consumption }\end{array}$ & t/ten thousand yuan & 20 & 50 \\
\hline & $\begin{array}{l}\text { Environmental protection investment of fiscal } \\
\text { expenditure proportion }\end{array}$ & $\%$ & 3 & 1 \\
\hline & Emission intensity of major water pollutants & $\mathrm{t} / \mathrm{km}^{2}$ & 1 & 3 \\
\hline & Emission intensity of major air pollutants & $\mathrm{t} / \mathrm{km}^{2}$ & 0.5 & 6.5 \\
\hline & Ratio of income between urban and rural residents & - & 1.5 & 2.5 \\
\hline & Per capita ecological footprint & global hectare & 1 & 2 \\
\hline
\end{tabular}

Table 4. Comparison of results of the various standardization methods.

\begin{tabular}{|c|c|c|c|c|c|c|}
\hline \multirow[b]{2}{*}{ Level } & \multicolumn{2}{|c|}{ Extreme standardization } & \multicolumn{2}{|c|}{$\begin{array}{l}\text { Single-benchmark progressive } \\
\text { standardization }\end{array}$} & \multicolumn{2}{|c|}{$\begin{array}{l}\text { Double-benchmark progressive } \\
\text { standardization }\end{array}$} \\
\hline & Number & Average score & Number & Average score & Number & Average score \\
\hline $\mathrm{A}$ & 1 & 85.29 & 0 & - & 0 & - \\
\hline B & 2 & 71.38 & 0 & - & 2 & 71.93 \\
\hline $\mathrm{C}$ & 8 & 63.30 & 9 & 64.50 & 13 & 64.21 \\
\hline $\mathrm{D}$ & 10 & 54.94 & 19 & 56.26 & 15 & 54.93 \\
\hline $\mathrm{E}$ & 10 & 44.87 & 3 & 47.99 & 1 & 49.07 \\
\hline
\end{tabular}


Table 5. Statistical results for the various standardization methods.

\begin{tabular}{lccc}
\hline Assessment level & Extreme standardization & $\begin{array}{c}\text { Single-benchmark progressive } \\
\text { standardization }\end{array}$ & $\begin{array}{c}\text { Double-benchmark progressive } \\
\text { standardization }\end{array}$ \\
\hline Average score & 55.89 & 57.85 & 59.73 \\
Median score & 54.74 & 58.09 & 59.82 \\
Maximum score & 85.29 & 69.85 & 73.79 \\
Minimum score & 38.05 & 47.34 & 49.07 \\
Dispersion & 8.28 & 4.42 & 5.34 \\
\hline
\end{tabular}

The average score based on the double-benchmark progressive method was the highest, followed by the scores from the single-benchmark progressive method and the extreme standard method. The differences between the mean values and the median values were small, as evaluated by the three methods. Among them, the result from the double-benchmark progressive method was the lowest. The data dispersion of the results from the extreme standard method was large (38.05-85.29 points), while that from the single-benchmark progressive method was smaller (47.34-69.85 points), and that from the double-benchmark progressive method was moderate (49.07-73.39 points).

Similarities existed among the provincial eco-civilization development results by the three methods. The ascending or descending ranking of the single-benchmark progressive method was 3.81 , whereas it was 2.90 for the double-benchmark progressive method.

In summary, the benchmark progressive method is more practical than the commonly used normalization method (extreme standardization), with the double-benchmark progressive method being more scientific than the single-benchmark progressive method.

\subsection{Analysis of the results based on the double-benchmark progressive method}

In this study, we eventually selected the double-benchmark progressive method to evaluate the level of eco-civilization de- velopment in 31 provinces, autonomous regions, and municipalities in 2014. The results are shown in Table 6. The results show that, in 2014, China's average eco-civilization development level score was 59.73, which was at level D. Among the areas, none reached level A, with only Zhejiang, Guangdong Province, which accounts for $2.98 \%$ of the area in China, being in a region where the eco-civilization developmental level B was achieved. Fourteen regions achieved level C, including Fujian, Hainan Province, accounting for $23.45 \%$ of the area in China; 14 regions achieved level D, including Jiangsu Province and the Inner Mongolia Autonomous Region, accounting for $69.08 \%$ of the area in China; while regions achieved level E included Gansu Province, accounting for $4.50 \%$ of the area in China. These results show that China's level of eco-civilization development remains low.

The eco-civilization development level of China's southeast coastal areas was slightly higher than that in the central and western regions. From the four areas evaluated (Fig. 3 and Table 6), the average green life score of each province, autonomous region, or municipality was 71.24 , while the green production score was low at 53.25 points.

The green governance scores for the level B regions were low, while the other fields' scores were greater than 70 . Therefore, the development of the level B regions was more balanced. Green living scores for the level $\mathrm{C}$ regions were high, while the green environment and green governance scores were 60-70 points. However, the green production score was low, which

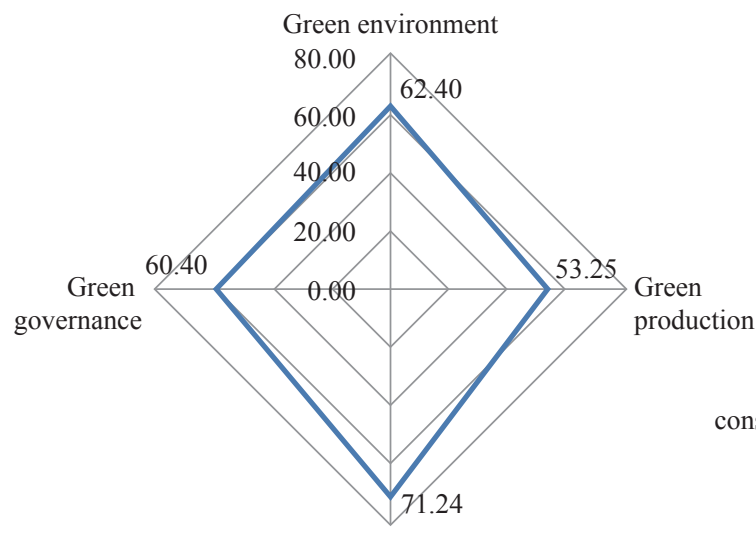

Green living

(a)

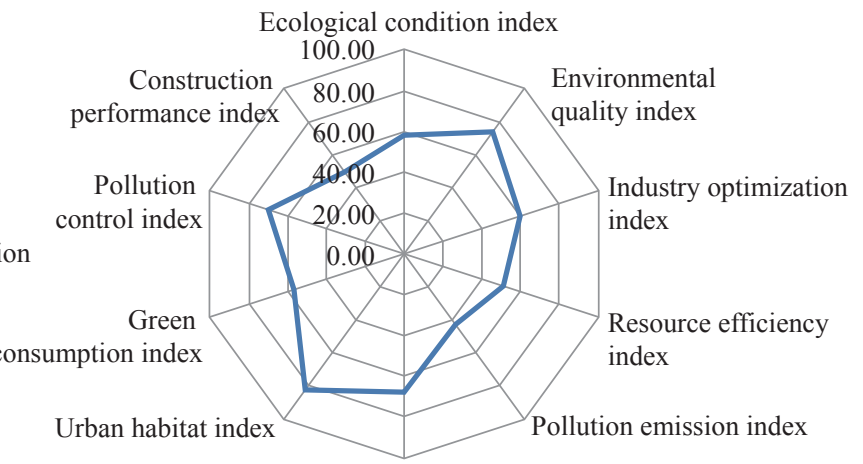

Urban-rural coordination index

(b)

Fig. 3. Radar map of the area and target layers. 
Table 6. Evaluation level based on the eco-civilization development index and field scores.

\begin{tabular}{lcccccccc}
\hline Level & Number & $\begin{array}{c}\text { Area ratio } \\
(\%)\end{array}$ & $\begin{array}{c}\text { Green } \\
\text { environment }\end{array}$ & $\begin{array}{c}\text { Green } \\
\text { production }\end{array}$ & $\begin{array}{c}\text { Green } \\
\text { living }\end{array}$ & $\begin{array}{c}\text { Green } \\
\text { governance }\end{array}$ & $\begin{array}{c}\text { Eco-civilization } \\
\text { development }\end{array}$ & Included areas \\
\hline $\mathrm{B}$ & 2 & 2.97 & 79.89 & 71.98 & 77.47 & 59.72 & 71.93 & $\begin{array}{c}\text { Zhejiang Province, Guangdong } \\
\text { Province }\end{array}$ \\
$\mathrm{C}$ & 14 & 23.45 & 66.95 & 56.11 & 73.98 & 63.81 & 63.90 & $\begin{array}{c}\text { Fujian Province, Hainan Province, } \\
\text { etc. }\end{array}$ \\
$\mathrm{D}$ & 14 & 69.08 & 55.63 & 48.83 & 68.48 & 57.60 & 54.58 & $\begin{array}{c}\text { Jiangsu Province, Inner Mongolia } \\
\text { Autonomous Region, etc. }\end{array}$ \\
E & 1 & 4.50 & 58.55 & 37.59 & 58.90 & 53.21 & 49.07 & Gansu Province \\
Average & & & 62.40 & 53.25 & 71.24 & 60.40 & 59.73 & \\
\hline
\end{tabular}

indicated that the green production was the short board in level $\mathrm{C}$ regions. The green living scores for the level D regions were greater than 60 points, while the other field's scores were below 60 points. The lower scores for the level D regions showed they were in the lowest level of eco-civilization in China.

The average urban habitat index, environmental quality index, and pollution control index scores of China's provinces, autonomous regions, and municipalities were 82.31 points, 72.65 points, and 70.52 points respectively, whereas the average scores for the pollution emission index, construction performance index, and resource efficiency index were 42.22 points, 49.11 points, and 50.71 points respectively.

To sum up, a gap still exists between China's level of eco-civilization development and the expected goals and the international level. Although some first-tier cities have achieved the international high-income level, with China's overall economy and social construction having made remarkable progress, the environmental protection, industrial pollution control, industrial optimization, and efficient use of resources need to be further strengthened to realize a balanced development of ecological civilization.

\section{References}

[1] Yan G, Wu M H, Fan Y C, et al. Annual report on China's provincial eco-civilization index (ECI 2015) [M]. Beijing: Social Sciences Academic Press (China), 2015. Chinese.

[2] School of Economics and Resource Management of Beijing Normal University, Institute of Development Studies of SWUFE, China Economic Monitoring \& Analysis Center of National Bureau of Statistics of the PRC. 2014 China green development index report: Regional comparison [M]. Beijing: China Science Publishing \& Media Ltd., 2014. Chinese.

[3] Dong Z F, Zhang X, Hao C X. Analysis and thoughts on 2014 environmental performance index [J]. Environmental Protection, 2015, 43 (2): 55-59. Chinese.

[4] Ministry of Environmental Protection of the PRC. Technical regulations of ecological environment assessment [M]. Beijing: China Environmental Science Press, 2015. Chinese.

[5] Hu Y H, He S H. Comprehensive assessment method [M].Beijing: China Science Publishing \& Media Ltd., 2000. Chinese.

[6] Dong Z F, H C X, Li H X, et al. Analysis of the environmental performance index: 2016 report [J]. Environmental Protection, 2016, 44(20): 52-57. Chinese. 